\title{
Relationship Between Prosocial Behavior and Intensity of Class Teachers Social Interactions to Special Needs in Inclusive Schools
}

\author{
Hudzaifah $^{1}$ \\ ${ }^{1}$ Universitas Sebelas Maret, Indonesia
}

\begin{abstract}
This study aims to determine the relationship of prosocial behavior with the intensity of teacher social interaction with children with special needs in inclusive schools in the city of Surakarta. The method used in this study is quantitative correlational methods. Sampling using purposive sampling, with the subject of the study amounted to 30 teachers in inclusive schools in the city of Surakarta. Data collection techniques use a scale of prosocial behavior and social interaction. The results of data analysis using Pearson Correlation Product Moment technique with the help of SPSS 23.0 program obtained a correlation of $r=0.919,(p>0.05)$, thus Ha was rejected and Ho was accepted. This shows that there is no significant relationship between prosocial behavior and the intensity of teacher social interaction with children with special needs in inclusive schools.
\end{abstract}

Keywords: prosocial behavior; social interaction; inclusive school.

\section{Introduction}

With the rapid development of special education and special services in Indonesia, children with special needs (ABK) not only attend special schools, but by considering social needs and abilities, public schools are starting to emerge which highlight certain programs where children with special needs directly intersect with other children of the same age in obtaining education.

According to Mangunsong (2009) children with special needs are children who have differences such as mental characteristics, sensory abilities, physical, emotional and social behavior, communication skills, or a mixture of two or more of the above than the average normal child. So that it requires changes to educational programs that lead to improvements in school assignments, learning methods or other services, which aim to develop students' potential and abilities to the full (Triyanto, 2016).

Inclusive Education is education that provides learning opportunities for all children without the exception of children with special needs (Anik 2017: Librarian 2012). With the existence of inclusive schools, it is hoped that it can stimulate the social

Article history: Received: September, 2020; Revised: January, 2021; Accepted: January, 2021 
development of children with special needs which are included in an environment that accommodates diversity (Anik, 2017).

Not without constraints, the existence of children in particular in inclusive schools also has various social problems such as social acceptance, support, and reasonable social interaction (Sihotang, 2017). Because of its limitations, children with special needs have less social quality than other peers. This happens because they tend to close themselves so they have weak social functions in society (Widuri, 2013).

In order for children to be confident, positive contact between children with special needs and regular teachers must be well-established. Positive contact can be realized by the existence of social interaction. According to Walgito (2003) social interaction is a relationship between individuals, which one individual can influence another individual or vice versa, so that mutual relations occur. The relationship can be between individuals and individuals, individuals with groups or groups with groups.

Furthermore, Soemantri (2005) explains with the existence of positive interactions between teachers and students, there will be a feeling of affection which is very helpful in delivering the goals of learning in inclusive schools. The existence of positive social contacts will lead to cooperation and the sense of needing help from others, while the negative interaction will

direct to a conflict or even does not produce a social interaction at all (D, S, Laras, et al., Rahmawati, E, et al. (2011). The purpose of social interaction is to actively enjoy and participate with other people, for example participating together in playing (Widuri, 2013). As Soekanto (2012) stated that, social interaction is the key to all social life because without social interaction there would not be possible life together.

When learning at school takes place not only the subject matter is given to the child, but also the learning process that deserves attention. Santoso (2010), mentions several points in the stages of social interaction, including at the second point in the social interaction stage, namely the existence of material and time, at this stage students need to have materials for social interaction such as important information, problems and material from life experiences, what is meant by material here is that the facilities provided are in the form of visual media, so that children are able to process the information given by the teacher.

In addition to teachers, administrative staff must also provide system support to deal with ABK's social interaction skills, namely in the form of participating in interacting with children both during breaks and when meeting in class (Widuri, 2013). In accordance with this, the child learns in a social situation in a group of togetherness situations. According to Gerungan (2009), the situation of togetherness is a situation of gathering a number of people who previously did not know each other and the social interactions between them were not previously profound. The aspects of social interaction according 
to Sarwono (2010) which underlie the emergence of social interactions, namely communication, attitudes, and group behavior.

So that positive social interactions can be formed. So beforehand there must be prosocial behavior among individuals involved in interactions. Prosocial behavior is voluntary action carried out to provide benefits to others (Bashori, 2017). Prosocial behavior can be obtained through direct or indirect experience. This type of behavior that benefits others is not only limited to helping actions such as volunteering, and donating, but can also refer to various other forms of positive behavior (Jannah. P.M, Djuwita. R, 2018). Prosocial behavior or helping help in everyday life can be understood as any behavior that benefits others. Prosocial Behavior (Prosocial Behavior) can also be interpreted as any action that benefits other people (Elvrida, 2016). Prosocial behavior aims to help improve the well being of others, because someone who acts prosocially helps to prosper and make the lives of people or beneficiaries happy (Bashori, 2017). Several aspects of prosocial behavior according to Baron and Branscombe (2012) are divided into 5 stages, namely awareness, interpretation of conditions, assumption of responsibility, skill in attitude, and decision making. Prosocial behavior occurs when there are two or more people who happen to be met in a situation where each other gives mutual behavior in terms of help. This is the same as stated. Thibaut and Kelley (in Ali and Asrori, 2006), as interaction theorists, explain interactions as interplaying events when two or more people meet to communicate with each other. The previous research on prosocial behavior in early childhood shows that the presence of prosocial behavior makes it easier for them to adjust to the school environment. With the explanation through the background above, this study specifically aims at a problem statement about how the relationship between prosocial behavior and the intensity of social interaction of classroom teachers in inclusive schools?

To find out the relationship, the objectives of this study were formulated, namely. Knowing the relationship between prosocial behavior and the intensity of social interaction between classroom teachers and children with special needs in inclusive schools.

\section{Research Methods}

This study uses a quantitative correlational approach with a research subject of 30 teachers selected by purposive sampling with details of 15 male teachers and 15 female teachers spread across several inclusion schools in Surakarta. This research was carried out on the vulnerable in September - October 2018. In this study, there are two variables that will be examined, namely prosocial behavior and social interaction between teachers-students with special needs. This study uses a Likert type psychology scale as a data collection technique from the two variables studied

Prosocial behavior variables were measured using the prosocial behavior scale according to Baron and Branscombe (2012) which included 5 aspects, namely awareness, 
interpretation of conditions, assumption of responsibility, skill in attitude, and decision making. Furthermore, the social interaction variables are collected using the Sarwono scale, 2010) which includes three aspects of social interaction, namely communication, attitudes, and group behavior. The data analysis technique used in this study is Pearson Correlation Product Moment with the help of SPSS 23.

\section{Results}

Research result Hypothesis testing of this study was carried out using Pearson analysis with correlation test if the significance value $(p)<0.05$ then there is a significant influence between variables, but if if the significance value $(p)>0.05$ then there is no significant influence between variables. Based on the results of the correlation calculation using Pearson Product Moment correlation, with the help of SPSS 23.0 with a significance value of 0.919 , it can be concluded that $\mathrm{Ha}$ is rejected and $\mathrm{Ho}$ is accepted which means there is no significant relationship between prosocial behavior and the intensity of teacher social interaction with children with special needs in inclusive schools.

\section{Discussion}

The results showed that there was no relationship between prosocial behavior and the intensity of teacher social interaction with children with special needs in inclusive schools in Surakarta with the acquisition of $p=0.919(p>0.05)$. As we know that Interaction can be intertwined because of contact, closeness, similarity, sympathy, and empathy. The research that shows that there is similarity can form an interaction and influence prosocial behavior, namely the research of Miller et al said that similarity is closely related to liking. Individuals will be more empathetic and more likely to help other individuals who like and have similarities or similarities to themselves (Myers, 2012). What was conveyed by meyer occurred in this study, where a teacher has good prosocial behavior but in terms of interaction, a teacher tends to be more interested in students who like him and have similarities or similarities in terms of physical abilities, intelligence, and mental similarities and interest.

Another thing that might be the cause of the absence of a relationship between prosocial behavior and the intensity of teacher-student interaction with special needs in inclusive schools in Surakarta is because of increasingly sophisticated technological developments that make someone, especially tend to lack socialization and social attitudes to fade. So it tends to do something based on its own interests. Sarwono, 2012. The manifestation of prosocial behavior also does not have to give rise to interactions between teachers and students with special needs, as stated (Iqbal, 2013), which explains that an individual tends to give indirect assistance rather than directly and the manifestation of helpful behavior will be different in each event and atmosphere. As for some events that show the low prosocial behavior that occurs in the community, as revealed (Liauw, 2014) which conveys the low prosocial behavior in society which in this 
case occurs in adolescents which is about the indifference of a teenage girl who refuses to give her seat to pregnant women on an electric train.

\section{Conclusion}

1. There is no significant relationship between prosocial behavior and the intensity of teacher social interactions with children with special needs in inclusive schools.

2. The manifestation of prosocial behavior also does not have to give rise to interaction between teachers and students with special needs but a teacher tends to give indirect assistance to students of children with special needs and their forms are different in each event and atmosphere.

3. Another thing that might be the reason for the absence of a relationship between prosocial behavior and the intensity of teacher-student interaction with special needs in inclusive schools in Surakarta is because of increasingly sophisticated technological developments that make someone, especially tend to lack socialization and social attitudes to fade. So it tends to do something based on its own interests

\section{References}

Ali, M. dan Asrori, Muhammad. 2004. Psikologi Remaja. Jakarta: PT Bumi Aksara.

Anik Lestaningrung . (2017). Implementasi Pendidikan Inklusif Untuk Anak Usia Dini di Kota Kediri (Studi Pada Paud Inklusif Ybpk Semampir,Kecamatan Kota, Kediri), Volume 4 Nomor 2, Jurnal CARE (Children Advisory Research and Education).

Baron, R.A. \& Branscombe, N.R. (2012). Social Psychology (13th Edition). Boston: Pearson Educatiom, Inc.

Bashori, K. (2017). Menymai Perilaku Prososial di Sekolah, Jurnal Pendidikan, Yogyakarta: Sukma.

Gerungan, W.A. 2009. Psikologi sosial. Bandung: Refika aditama

Iqbal, F. (2013). Prosocial behavior in different situations among men and women. IOSR Journal of Humanities And Social Science (IOSR-JHSS). 8(6), 31-40.

Jannah. P.M, Djuwita. R (2018). Intervensi Peningkatan Perilaku Prososial dalam Upaya Menurunkan Perundungan,Pesona: Jurnal Psikologi Indonesia: UI.

Kustawan, D. (2012). Pendidikan Inklusif dan Upaya Implementasinya. Jakarta: Luxima.

Liauw, H. (2014). Tidak simpatik dengan ibu hamil di KRL, perempuan di path dikecam. Kompas.From http://megapolitan.kompas.com/read/2014/04/16/1623529/Tak.Simpatik.denganl buHamil.di.KRL.Perempuan.di.Path.Dikecam.

Matondang, E, A. (2016). Perilaku Prososial (Prosocial Behavior) Anak Usia Dini Dan Pengelolaan Kelas Melalui Pengelompokan Usia Rangkap (Multiage Grouping), Vol. 8. No.1, Jurnal Pendidikan Dasar, : EduHumaniora.

Myers, D.G. (2012). Psikologi sosial edisi 10 buku 2. Jakarta: Salemba Humanika. 
Rahmawati, E, dkk, (2011). Social Interaction in Nature-Based Tourism at Gunung Salak Endah Community, Jurnal Forum Pascasarjana, Bandung: IPB.

Santoso, Slamet. 2010. Teori-Teori Psikologi Sosial. Bandung: Refika Aditama

Sarwono, S.W. (2012). Psikologi remaja. Jakarta: Rajawali Pers

Sarwono, sarlito. 2010. Pengantar Psikologi Umum. Jakarta: PT Grafindo Persada

Soekanto, S. 2012. Sosiologi Suatu Pengantar. Jakarta: PR Raja Grafindo Persada.

Somantri, T.S. 2005. Psikologi Anak Luar Biasa.Bandung: Refika Aditama

Triyanto, Desty R. P. (2017). Pemenuhan Hak Anak Berkebutuhan Khusus di Sekolah Inklusi. UNS.

Triyanto, Desty R.P. (2017). Pemenuhan Hak Anak Berkebutuhan Khusus di Sekolah Inklusi. UNS.

Triyanto, Desty R.P. (2017). Pemenuhan Hak Anak Berkebutuhan Khusus di Sekolah Inklusi. UNS.

Walgito, Bimo. 2003. Psikologi Sosial (Suatu Pengantar). Yogyakarta: Andi

Widuri, R.W. (2013). Penanganan Kemampuan Interaksi Sosial Anak Autis, Jurnal Pendidikan Khusus,Surabaya: UNNES. 